\title{
Museum Technologies of the \\ Disabled Persons' Social Adaptation in the Russian Federation
}

\author{
Larissa Iu. Anisimova \\ and Anastasiia M. Selivanenko* \\ Siberian Federal University \\ 79 Svobodny, Krasnoyarsk, 660041, Russia
}

Received 15.07.2016, received in revised form 19.09.2016, accepted 08.11.2016

The article analyzes the experience of using the cultural heritage by the disabled people. It presents the Russian experience of making use of museum communication means in working with the disabled, including the experience of Eastern Siberia. Traditional and innovative adaptation mechanisms involving the museum exhibition complexes availability are described. The authors argue that modern museum technologies have a great impact on the society's adequate attitude towards the disabled. As cultural institutions the museums have a particular potential in the field of socio-cultural adaptation of the disabled people.

Keywords: integration; adaptive approach; museum art-therapy; museum-reserves; museum technology of socio-cultural adaptation.

DOI: 10.17516/1997-1370-2016-9-12-2866-2872.

Research area: culture studies.

\section{Introduction}

The disabled people around the world are involved in all spheres of social life and use its achievements. This article summarizes the experience of the disabled people's participation in museum activities. It is known that in modern conditions museums act as cultural and scientific-and-educational centres, they develop and adapt to the changing socio-cultural space and the world museum community. The Russian researchers I.N. Donina, O.N. Shelegina, et al. note that as cultural institutions museums have a particular potential in the field of the disabled people's socio-cultural adaptation, tolerance development, and they are considered a vector of further development (Donina, 2014; Shelegina, 2012).

While developing the programmes for the disabled the Russian museums use innovative methods (audio-tours, tailored tours, museum and art-therapy) with great potential of using visual art and museum environment for a personality's harmonization. They favour the development of an ability of self-expression and self-knowledge, achievement of positive changes in a human's emotional, intellectual, and personal development.

(C) Siberian Federal University. All rights reserved

* Corresponding author E-mail address: severyanova@mail.ru 
Museums make use of museum-pedagogical and universal design technologies when working with children from low-income families, orphans, and disabled teenagers.

Legislative and regulatory frameworks, governing the relationship of the museums with the disabled, are guaranteed in current international and domestic legislation. In 2011 the state programme "Accessible environment" was adopted in the Russian Federation (RF) for the period of 2011-2015. Development of normative legal documents, provision of the conditions of accessibility of social infrastructure objects, creation of favorable conditions for the integration of the disabled into the society are priority objectives of this programme.

The conception of the museum activities development in the Russian Federation till 2020 formulates the need to provide the museums with equipment, enabling the disabled people to visit and participate in the museum programmes.

\section{Domestic experience}

Russian museums have been developing cultural and educational programmes of acute social orientation, introducing special methods of serving the disabled people of different categories into their practice. For example, the recreation therapists of "Reakomp", the Institute of All-Russian Society of the Blind, and the staff of the State Darwin Museum (Moscow) have successfully tested the methodology of social and cultural rehabilitation of the disabled by means of the museum facilities in the Moscow Association "Moscow City Museum", The Timiryazev State Biological Museum, the Moscow State Museum "Bourganov's House", the Pushkin State Museum, etc. (Van'shin, Van'shina, 2009). The State Darwin Museum or "Museum without Barriers" runs special tours for children with mental activity disorders (an individual programme, taking the extent of the disease and age into account, is prepared for each group), sightseeing tours of the museum for wheelchair users, sightseeing tours of the main exhibition for the disabled people with the musculoskeletal system disorders, sightseeing tours of the main exhibition for the blind and visually impaired people while using a relief-graphic guide, sightseeing tours of the main exhibition for the visitors with hearing disorders (sign language, provision with a text version of the tour), sightseeing tours of the main exhibition for the disabled pensioners. A sightseeing tour implies relief-graphic aids: stuffed animals and birds, pieces of mammals' fur and skin can be touched. The museum hosts such interactive sessions and workshops displaying various forms of life as "Metamorphosis of a Butterfly", "Life of the Insects", and "Evolution of the Organic World". There is an electromagnetic two-circuit converter in the cinema hall of the State Darwin Museum. It is designed to transfer voice messages and music to hearing impaired visitors who have hearing devices with the "phone" mode, thus making it possible for the disabled visitors to actively participate in the events and celebrations of the museum.

Implementation of the projects has resulted in the appearance of the area without barriers in the museum surroundings. In the Russian Museum (Saint-Petersburg) both long-term and short-term programmes of the museum art therapy classes are put into practice. The classes favour social adaptation and rehabilitation of the disabled children and people in difficult life situations by means of museum environment, learning and fine arts classes. In 2012 the Russian Museum introduced a programme of organizing an available cultural and educational environment for the disabled people as well as for adolescents and young people in difficult life situations. 21 projects were implemented in the course of a year. 1650 people participated in these projects, and namely: 
- orphaned children living in orphan asylums of St. Petersburg and Leningrad oblast;

- persons with disabilities of locomotor apparatus at the age from 4 to declining years;

- visually impaired and blind children, adults;

- deaf and hearing impaired children and adults;

- mentally challenged children, adolescents and young people;

- children suffering from severe mental diseases;

- adults with a psychiatric diagnosis;

- young drug addicts under rehabilitation and their families;

- young delinquents from specialized educational institutions.

In the thesis "Museums in the disabled people's socio-cultural adaptation" I.N. Donina examined the use of museum-pedagogical technology in the process of socio-cultural adaptation of the disabled and developed a number of recommendations for carrying out cultural and educational activities while taking the museum visitors' physical, sensory and mental limitations into account. According to I.N. Donina, "a currently leading method for interacting with the individuals with hearing disorders is the method of oral discourse, consisting of several techniques, the techniques being pronunciation (basing upon visual analyzer, when a visitor sees a museum educator's clear articulation); finger spelling when a certain combination of fingers stands for a certain sound; demonstration; captions. The author suggests displaying bright, eye-catching exhibits with a small number of minor details for this category of visitors. Interaction with the audience with visual disabilities implies awareness of possible mixed composition of groups, including visually impaired visitors and those with residual vision and totally blind. The audience with impaired visual perception can be also offered the method of tiflocommenting, description, or, in western terminology, audiodescription for the blind" (Donina, 2014, p. 8990).

Unlike other cultural institutions, museumreserves are designed to preserve the integrity of architectural, archaeological or memorial monuments, historic areas, including unique cultural and natural landscapes, historic urban and rural settlements, and lifestyle of the population living in historic areas. Museum-reserves actively involve children. They constantly work with them and participate in the programmes of school education. They organize various holidays for the local population, participate in many activities of cultural and educational services, and take a part of social concerns of serving the elderly upon themselves. For example, the state historicalarchitectural, art and landscape museum-reserve "Tsaritsyno" (Moscow) implements more than 17 interactive educational programmes and workshops for the disabled visitors. "See the picture", a special educational programme for people with visual disabilities - blind and visually impaired visitors of any age - are worth mentioning. The visitors are immersed into the atmosphere of the late XVIII century with the help of a guide's story and tiflocommenting, as well as tactile inspection of interior parts, sculpted portraits of emperors, grand princes and artists of the XVIII century.

Moreover, the technical equipment of the museum meets all modern regulations and requirements of the Federal law No. 181-FZ dated 24.11.1995 (amended on 29.06.2015) "On social protection of invalids in the Russian Federation". Thus, there appeared elevators and lifts, ramps and handrails, parking spaces for the disabled people's private vehicles for those who have difficulties while moving. Toilet cubicles for wheelchair users are equipped with the devices for the disabled as well as with a panic alarm 
button. Free chair-walkers are provided for use during the tours and individual exploration of the Grand Palace and the Bread House; individual wheelchairs are provided for moving around the territory.

A relief map of the central part of the Palace and Park ensemble territory and an album of notation conventions written in Braille (available for free when asking an administrator at the Tour Desk in the Visitor Centre and the Front entrance lobby) are developed for visually impaired visitors. There are also the models of the "Tsaritsino" Palace and Park ensemble on the palace part of the territory. Permanent exhibits in the Grand Palace and the Bread House have captions in Braille.

Moreover, special equipment to amplify sound is installed for the museum visitors with hearing impairments, the equipment being the Aurica induction system and induction magnetic loops to enhance the sound signal to the hearing aid when using the audio guide.

\section{The experience of Siberian museums}

The Russian museums have accumulated some experience of interdepartmental cooperation. So, the Russian Museum has been implementing the "The Art Museum Volunteers' School" educational project aiming at training the specialists of social work and senior students of humanitarian universities within the "Development of the art therapy methods and their practical application" programme. The State Darwin Museum closely cooperates with the centres of social service for the citizens of advanced age and the disabled of St. Petersburg (Ibid., p. 100).

The "Tomskaia Pisanitsa" State Historical-Cultural and Natural MuseumPreserve (Kemerovo) in collaboration with the State Russian Museum holds awarenessraising and training seminars on art therapy in culture and education (Bulgakova, 2015). To integrate and adapt the disabled in the society the museum network cooperates with the local authorities, social welfare bodies, volunteers and educational institutions. The staff of the "Tomskaia Pisanitsa" museum-preserve in cooperation with the psychologists of the social rehabilitation center for the underage has developed an innovative programme of the museum art therapeutic workshop "Live drawings" (Ibid.).

Siberian museums contribute to the process of rehabilitation, social adaptation and integration of mentally or physically challenged children and adults. For example, the State Historical and Ethnographic Museum-Reserve "Shushenskoe" in Krasnoyarsk krai systematically invites to its educational programmes ("A Young Family in the Museum", "A Day in the Museum" (for inmates of children's homes), "To Hear with the Heart" (for the disabled children)). In 2014 the number of such events was 278 with 6579 visitors. In 2013 the summer ethnographic event for the teens at risk "Summer-2013" was organized at the museum. 18 events were held during that year, they were attended by 1221 visitors. The same year the museum-reserve "Shushenskoe" organized the "Shushenskaia Lad'ia" ("Shushenskaia Castle") regional chess tournament for the inmates of children's homes of the southern regions of Krasnoyarsk krai and veterans of sport.

The territory of the architecturalethnographic museum "Angarskaia Derevnia" ("The Angara Village") in Irkutsk oblast also hosts festivals and morning performances for the socially unprotected citizens (A Young Family Day, Christmas parties for kids, "Help a child and save the world" marathon, charity tours). This is presented in Table 1 providing the information about the museum activities for the certain categories of visitors in 2014. 
Table 1. The work of the museum with the certain categories of visitors (the disabled, children from low-income families, orphans, children left without parental care)

\begin{tabular}{|c|c|c|}
\hline Events & Number of visitors & The visitors \\
\hline "I'm not afraid of frost" game programmes & 32 & children left without parental care \\
\hline The event for the society of the disabled people & 50 & the disabled \\
\hline The "Holy Easter" holiday & 40 & orphaned children \\
\hline "Schools of Bratsk area in the war years" lecture & 72 & children from low-income families \\
\hline "The Battle at the Padun" lecture and film show & 73 & orphaned children \\
\hline Workshops on manufacturing of glove puppets & 30 & orphaned children \\
& 35 & the disabled \\
\hline $\begin{array}{c}\text { The exhibition of the disabled people's creative works } \\
\text { "The Impossible is Possible" }\end{array}$ & 200 & children in difficult life situations \\
\hline "At the Samovar" event & 60 & \\
\hline
\end{tabular}

\section{Conclusion}

The analysis of the Russian museums' activity on the disabled persons' adaptation to socio-cultural environment proves its relevance for the disabled, their adaptation to socio-cultural rehabilitation and adaptation in the society, arrangement of new conditions for perception of the museum environment, realization of children's creativity and overcoming of socio-cultural isolation of the disabled. Although such museum activity has important scientific and practical significance, the experience of the Russian museums is only at the start of generalization and requires a separate research.
Practical experience of the Siberian museums in implementation of cultural and educational initiatives for the disabled has revealed a number of issues to be solved. Firstly, it is necessary to improve technical equipment of the museums, including audiovisual and information equipment, interactive funds of objects such as replicas, dummies and models, items necessary for interpretation of the exhibition space. Secondly, interactive areas for creative activities should be arranged in the museums. Thirdly, the forms of targeted work with the disabled should be widely introduced.

\section{References}

Art-terapiia. Ofitsial'nyi sait rossiiskogo tsentra muzeinoi pedagogiki i detskogo tvorchestva Russkogo muzeia [Art-Therapy. The Official Website of the Russian Center of Museum Pedagogy and Children's Crafts of the Russian Museum]. Available at: http://www.muzped.net/ocentre (accessed 11 October 2015).

Ashaev, S.V. (2010). Formy raboty v muzee s liud'mi c ogranichennymi vozmozhnostiami [Forms of Museum Work with the Disabled People], In Omsk Scientific Bulletin, 4 (189), 219-222.

Bulgakova, V.V. (2015). Teoreticheskie i metodologicheskie aspekty sotsiokul'turnoi integratsii invalidov v muzeinoi srede [Theoretical and Methodological Aspects of Socio-Cultural Integration of the Disabled people in the Museum Environment], In Bulletin of Kemerovo State University of Culture and Arts, 30, 96-106. 
Donina, I.N. Muzei v sotsiokul'turnoi adaptatsii invalidov: dis. ... kand. kul'turologii [Museum in Socio-Cultural Adaptation of the Disabled: Dissertation of Candidate of Cultural Studies]. St.Petersburg, 2014.

Kontseptsiia razvitiia muzeinoi deiatel'nosti v Rossiiskoi Federatsii na .period do 2020 goda: reshenie № 3 kollegii Ministerstva kul'tury Rossiiskoi Federatsii ot 7 fevralia $2013 \mathrm{~g}$. [The Concept of the Museum Activities Development in the Russian Federation for the Period up to 2020: decision No. 3 of the Board of the Ministry of Culture of the Russian Federation, dated 7 February 2013]. Available at: mkrf.ru/upload/mkrf/mkdocs2013/20_02_2013_1.pdf (accessed 22 October 2015).

Muzei bez bar'erov. Ofitsial'nyi sait gosudarstvennogo Darvinovskogo muzeia [Museum without Barriers. The Official Site of the State Darwin Museum]. Available at: http://www.darwinmuseum. ru/_forvisitors/?dir=invalid (accessed 22 October 2015).

O gosudarstvennoi programme Rossiiskoi Federatsii "Dostupnaia Sreda" na 2011-2015 gody: Postanovlenie Pravitel'stva Rossiiskoi Federatsii ot 17 marta 2011 g. № 175 [On the State Program of the Russian Federation "Accessible Environment" for 2011-2015: The Decree of the Government of the Russian Federation No. 175, dated 17 March 2011]. Available at: http://www.invalidov.net/viewtopic. php?id=371. (15 October 2015).

O sotsial'noi zashchite invalidov v Rossiiskoi Federatsii: Federal'nyi zakon ot 24.11.1995 № 181FZ (red. ot 29.06.2015) [On Social Protection of Invalids in the Russian Federation: Federal Law No. 181-FZ, dated 24 November 1995 (amended on 29.06.2015). Available from the "ConsultantPlus" information-and-legal system.

Ob utverzhdenii gosudarstvennoi programmy Irkutskoi oblasti "Sotsial'naia podderzhka naseleniia" na 2014-2018 gody: Postanovlenie Pravitel'stva Irkutskoi oblasti ot 24 oktiabria 2013 goda N 437-pp. [On Approval of the State Target-Oriented Programme of Irkutsk Oblast "The Social Support of the Population" for 2014 - 2018: The Decree of the Government of Irkutsk Oblast No. 437-pp, dated 24 October 2013]. Available from the "ConsultantPlus" informationand-legal system.

Otchet muzeia-zapovednika "Shushenskoe" za 2014 god [Report of the museum-reserve "Shushenskoe" for 2014]. KGBUK Istoriko-etnograficheskii muzei-zapovednik "Shushenskoe". F. 1. Op.1. D. 1559 [Krasnoyarsk State Budget Cultural Institution "Historical and Ethnographic MuseumReserve "Shushenskoe". F. 1. Inv. 1. File 1559].

Otchet MUK "Bratskii gosudarstvennyi ob'edinennyi muzei osvoeniia Angary" za 2014 god [Report of the Municipal Cultural Institution "The Bratsk State Joined Museum of the Angara Development” for 2014]. MUK “BGOM”, g. Bratsk [The Municipal Cultural Institution "The Bratsk State Joined Museum", the city of Bratsk].

Programmy dlia posetitelei s ogranichennymi vozmozhnostiami [The Programmes for the Disabled Visitors]. Ofitsial'nyi sait muzeia-zapovednika "Tsaritsyno" [The Official Site of the Museum-Reserve "Tsaritsyno"]. Available at: http://www.tsaritsyno-museum.ru/education/ interactive/disabled/index.php (accessed on 29 October 2015).

Shelegina, O.N. Istoriia i sovremennye tendentsii v razvitii muzeinogo mira Sibiri (adaptatsionnyi period): avtoreferat dis. ... doktora istorich. nauk [History and Current Trends in the Development of the Museum World of Siberia (Adaptive Approach): Author's Abstract of Dissertation of Doctor of Historical Sciences]. Tomsk, 2012. 54 p. 
Usloviia poseshcheniia dlia liudei s ogranichennymi vozmozhnostiami [Conditions for the Disabled Museum Visitors]. Ofitsial'nyi sait muzeia-zapovednika "Tsaritsyno" [The Official Site of the Museum-Reserve "Tsaritsyno”]. Available at: http://www.tsaritsyno-museum.ru/visitors/disabled/ index.php (accessed on 15 October 2015).

Van'shin, S.N., Van'shina, O.P. Sotsiokul'turnaia reabilitatsiia invalidov muzeinymi sredstvami [Socio-Cultural Rehabilitation of the Disabled People by Museum Means]. Moscow, GDM, 2009. $76 \mathrm{p}$.

\section{Музейные технологии}

\section{социальной адаптации людей}

с ограниченными возможностями

в Российской Федерации

Л.Ю. Анисимова, А.М. Селиваненко

Сибирский федеральнылй университет Россия, 660041, Красноярск, пр. Свободньй, 79

В статье проанализирован опыт использования культурного наследия для людей с ограниченными возможностями. Изучен российский опыт, в том числе и Восточной Сибири, применения средств музейной коммуникации в работе с инвалидами. Рассмотрены традиционные и инновационные механизмы адаптации, предполагающие доступность музейных экспозиционных комплексов. Авторы считают, что современные музейные технологии оказывают больиое влияние на адекватное отношение общества клицам с ограниченныли возможностями, а музей как учреждение культуры обладает особым потенциалом в области сочиокультурной адаптации инвалидов.

Ключевые слова: интеграция, адаптационный подход, музейная арт-терапия, музеизаповедники, музейная технология социиокультурной адаптаџии.

Научная специальность: 24.00.00 - культурология. 